\title{
Collaborating with a Dead Man: The Cultural Politics of Ahmed Yerima's Otaelo
}

\section{Abstract}

Several contemporary adaptations of Shakespeare address important, as well as ongoing, sociocultural and political situations in their various societies. While this approach suggests collaboration with Shakespeare rather than contesting of the colonial political and cultural hegemony that the English Bard privileges, it also underlines the influence that Shakespeare has on the writers and cultures with which he has been in contact. From the perspective of collaboration with Shakespeare through Othello, this essay examines Ahmed Yerima's Otaelo, which dramatizes the debilitating and tragic effects of the Osu practice among the Igbo people of southeast Nigeria and emphasizes the play's strong echoes of other plays by Shakespeare, including Hamlet, The Merchant of Venice, and Titus Andronicus. Yerima's play underlines how adaptation makes it possible to view the relationship between an older writer and a young (or new) one in the context of both influence and collaboration.

Keywords: adaptation, collaboration, Osu, Shakespeare, social reality, Yerima

Shakespeare is, here, now, always, what is currently being made of him. (Holderness xvi)

In the General Introduction to their highly informative book on adaptations of Shakespeare, Daniel Fischlin and Mark Fortier observe that:

Sometimes ... those who adapt Shakespeare admire the original, are interested in a kind of collaboration with Shakespeare, or make use of Shakespeare's status to authorize their own work [and] borrow from Shakespeare's status to give resonance to their own efforts. (6) 
The authors also inform us that any cultural work, including adaptation, should be studied in its relation to the political issues that play out within it since "any work of culture has a history in which its political import is repeatedly transformed" (6). In order to give greater resonance to his own play, Otaelo, which he locates in history, the Nigerian playwright Ahmed Yerima also collaborates with and uses Shakespeare's status. Since the colonial period, Shakespeare has become not just "the quintessence of Englishness and a measure of humanity itself" (Loomba and Orkin 1) - the English Bard was considered "a prime signifier of imperial cultural authority" (Tompkins 15) in former British colonies. Reworkings of his plays in the postcolonial world have therefore largely contested the political and cultural hegemony that Shakespeare represents and hence are termed "canonical counter-discourse," following Helen Tiffin and her description of how the new plays seek to "destabilize the power structure of the originary text(s)" (22) by seeking to "deconstruct significations of authority and power exercised in the canonical text, to release its strangle hold on representations and, by implication, to intervene in social conditioning" (Gilbert and Tompkins 16). However, Yerima is neither concerned with "rewritings that would give voice to the voiceless [and] reveal the other side of a canonical European work and undermine its master-narrative" nor is he interested in "fragment[ing] the classic text to intersperse it with new material and reverse its ending" (Doring 82). Rather, Yerima's adaptation is informed by the idea of reworking Shakespeare as cultural translation that is useful in addressing his own social concerns.

Otaelo is supposedly an adaptation of Othello. Supposedly in the sense that, while the play uses the context of Othello to dramatize the danger and tragedy of Osu, a socio-cultural practice based on segregation and marginalization among the Igbo people of southeast Nigeria, and similar in many ways to racism (and otherness) at the centre of Shakespeare's Othello, it also borrows heavily from other plays by Shakespeare including The Merchant of Venice, Hamlet, and Titus Andronicus. A. C. Bradley's statement that "Othello is a drama of modern life ... the characters come close to us and the [effect of the] application of the drama to ourselves is more immediate" (171) may as well apply to Otaelo in the way that it engages an ongoing reality and social concern and demonstrates both the admiration and collaboration of a young (and new) writer with an older one, as well as a correspondence between the two writers separated by both temporal and spatial divide. Shakespeare adaptations, as Linda Burnett writes, are "a postcolonial enterprise" and "a 
patchwork quilt of many perspectives" (7). It is not about how "to rip out and replace old patches with new [ones] or to start the quilt from scratch, but to add to an ongoing work" (Burnett 7 ). This essay examines how Yerima uses Othello and other plays by Shakespeare to address his own society. In doing so, the essay draws from the existing scholarship on Shakespeare, including Jan Kott's and Ania Loomba's works. It also emphasizes the significance of wish fulfillment and sexuality, the unconscious and repression, to the central character of the play through the perspective of cultural studies.

Yerima's example must be viewed against the background of Jan Kott's existential humanist analysis of the works of Shakespeare in his influential book, Shakespeare Our Contemporary. Whereas Marjorie Garber asserts that "every age creates its own Shakespeare" (3), Kott contends that "Shakespeare's universality has never dated" (131) because "Shakespeare does not need to be modernized or brought up to date. History ... finds its reflection in [the plays], in every age" (204). As such, Kott's existentialist approach to the analysis of Shakespeare, or what he calls "contemporization," urges us to also discover how "Shakespeare means", that is, the ways in which his plays are useful to understanding relations among people and the historical conditions that define our own time and place.

Northrop Frye writes that "Shakespeare's plays are existential facts and no understanding of them can incorporate their existence" for in those plays "the past is [often] blended with the present" (51). Similarly to a number of contemporary dramatists who aim to help us rediscover ourselves through their own engagement with the Shakespeare canon, Yerima collaborates with Shakespeare in a way that suggests an adoption of the Kottian existentialist approach in order to use his play, Otaelo, to address a matter of cultural and political concern in Nigeria. As John Drakakis writes, "Shakespeare can never be 'our contemporary' except by the strategy of appropriation" (24). Yerima collaborates with Shakespeare by drawing inspiration first from Othello, as he admits in the "Author's Note" to the play (6), and from sources other than the hypotext that he claims to have adapted. Yerima's approach recalls Diana E. Henderson's "diachronic collaboration" (1) in that he locates Otaelo in its own specific cultural moment, and in that he finds in his own play a sort of "socio-political resonance" (8) with Shakespeare's. In Henderson's opinion, the choice of "collaborating with a dead man," one that is unarguably the "exceptionally 
absent presence" - that is, Shakespeare - while affirming both human and creative agency along with the political and emotional temperament that propels and sustains it, also underscores "the connections among individuals, allowing artists credit and responsibility, but at the same time refusing to separate them from their social location and the work of others" (8). Collaboration of this kind, Henderson contends, has to do with "specific, personal choices" made by new writers in their handling of the work(s) of an older one which inform the creation of a new work from the previous one through the strategy of substitution that aids the new creators in their "struggle with both history and their own modernity" (23). In Fragmented Thoughts, Yerima admits such collaboration that Henderson articulates. He writes that

the play is based only on Shakespeare's theme of jealousy and intrigue. The adaptation is based on the Igbo osu tradition, and the characters' names change, the situation changes, the sensibilities change, but the 'jigida' which is the new symbol of love which represents the handkerchief of Shakespeare's original play still serves as the destructive metaphor in the adaptation. (124)

Shakespeare scholars have argued that we discover ourselves in our own historical moment through our own experience of Shakespeare's plays. Yerima also shows through Otaelo that it is possible to "find a new historical place, a new historical time for Shakespeare" for, indeed, "to be oneself means only to play one's reflection in the eyes of strangers" (Kott 270). However, other than Othello, Yerima equally draws inspiration for Otaelo from other plays by Shakespeare including The Merchant of Venice, Hamlet, and Titus Andronicus, in an approach that allows us to sidestep the notion of influence and emphasize instead collaboration, which occurs where, as Kevin Brophy argues, "the relationship [between an older writer and a new one is] one of respect, of the kind of to-and-fro that comes from repeated re-reading", which is clearly at work in Yerima's announced respect for Shakespeare and handling of his texts. After all, "the idea of collaboration lies at the heart of the artistic process" (Henderson 2). The rest of this essay examines the nature of the collaboration between Shakespeare and Yerima, the ways in which Otaelo echoes the aforementioned plays by Shakespeare, and how it addresses the concerns that Yerima considers important; but first, it introduces the Osu in its Igbo historical background and in the context of Yerima's play. 
Started as a form of religious devotion long before the British colonization of Nigeria, the Osu is a system of social stratification that is sanctioned by age-long tradition, and it survives today under several names including Adu-Ebo in Nzam in Onitsha, Oruma in the Nsukka area, and Nwani or Ohualusi in Agwu area among many others (Dike). At its very beginning, anyone could dedicate themselves as Osu regardless of gender, clan, and/or tribal affiliation within the larger Igbo society. By dedicating themselves to serve the gods of the land, these individuals gained respect and certain social privileges, such as the status of a "priest" or "saint." However, these privileges, including immunity from prosecution or torture of any kind, exemption from tax payment and all forms of communal labor, came at a price: having become an Osu, such individuals were automatically ostracized from the rest of the society. An Osu no longer had friends and could only marry other Osu; they lived in isolation, except within their own very small and limited class. In spite of this cost, however, the protection and benefits accorded to the Osu made it an attractive prospect to criminals, and especially perpetrators of those crimes that were regarded as the most heinous, namely, murder and incest. Hence the abuse worked both ways: just as criminals were eager to avail themselves of protection from prosecution, Igbo society at large came to regard Osu as a means of purging criminal elements and remaining peaceful. Over time, the Osu practice began to lose its value because some people began to take advantage of the gains it offered. The motivation to serve the religious needs of the society was replaced by personal gain, hence the Osu practice became dangerous and loathed (Idika 23-4).

There were many ways of becoming an Osu, such as devotion by choice and the picking of Nzu leaves heaped in front of a shrine in order to avoid molestation or death after committing a grievous crime, among several others. Yerima chooses as the subject for Otaelo the form of "Osu becoming" in which a person can become an Osu by crossing the inner sanctuary of a shrine. He then links it with the social reality of the Osu origin that is already marred by degeneration and abuse, and then uses Shakespeare's Othello as a canvas to paint the violence that the Osu practice represents. In the back story of the play, the central character, Otaelo, becomes an Osu when his mother runs into the shrine of the earth-god, Ala, for protection, after killing her husband in self-defense. First, she has committed murder, which is a crime punishable by death. Secondly, it is forbidden for a pregnant woman to enter the shrine and/or the inner sanctuary of Ala under any 
circumstance. She is executed for the first crime after giving birth to Otaelo, who also becomes an Osu on account of his mother's second crime. As it is apparent, while criminals decided to become Osu in order to escape punishment for their crime in the early stages of the Osu practice, Yerima's adaptation focuses on Otaelo, who is criminalized by society with the tacit support of Ala for an offense that he did not commit. Thus, throughout his entire life, which eventually ends in tragedy, Otaelo struggles with his identity and is treated worse than a slave. In questioning the rationale behind the continued veneration of the Osu tradition in contemporary time, Yerima takes on the big issues of identity, ostracism, abuse, and vengeance, for Otaelo dramatizes through the tragedy associated with the Osu tradition a "veiled allegory of internal colonialism" (Henderson 48), and it is here that one begins to see how Yerima moves out of Othello into The Merchant of Venice.

Umuagu, the prototype Igbo community and setting of Otaelo, is similar to Shylock's Venice in The Merchant of Venice in terms of the class stratification of society. Shylock and his daughter Jessica are Jews. According to Ania Loomba,

[b]oth [are] insiders and outsiders, with deep roots in Europe, but also with long histories of persecution and migration. They were often indistinguishable, both physically and in terms of their activities, from the local populations, and yet they were marked as different, ideologically and often literally through clothing and confinement in ghettos. That difference was elusive, hard to define, and yet culturally central, and this is the dynamic encoded in The Merchant of Venice. (141)

Although Otaelo closely follows Shakespeare's plot and the themes of jealousy and intrigue in Othello, Yerima's protagonist, Otaelo, questions why he is loathed by society through echoing Shylock instead of Othello. Like Shylock, who questions the basis of the social revulsion toward him and asks Solanio and Salerio, "Hath not a Jew eyes? Hath not a Jew hands, organs, dimensions, senses, affections ... If you prick us do we not bleed? If you tickle us do we not laugh? If you poison us do we not die? And if you wrong us shall we not revenge?" (3.1.47-58), Otaelo demands some answers from his adoptive father, Ebuka: "Always you want me to grovel in the mud searching for who I am. Does blood not flow in my veins? Do I not cry, laugh or feel the pangs of pain like anybody? Why must I always lose everything? Why can I not just be a man?" (34-35). Otaelo detests both ostracism and the harsh treatment meted out to him by society. He tells Ebuka: "What did I do wrong? Did I ask to be born by [my mother]? In obeying the nature of birth 
and passing through her passage of life, I offended the earth. That singular act, through no fault of mine makes me today an untouchable. Go old man, I say go, you choke me with pity" (35). In the final effort to extricate himself from social repulsion and the throes of the anguish resulting from his segregation, Otaelo resorts to vengeance; the play thus ends in a manner that is similar to Titus Andronicus.

In Umuagu, Yerima paints a dreadful picture of battle, anger, and vengeance that is similar to the 4th-century AD Roman Empire of Titus Andronicus, with its waning glory that is sustained by violent military campaigns. Loomba writes that empires like this particular Roman Empire "need to expand, to annex territories and peoples outside themselves into their boundaries, and as they do so, to underline differences between themselves and those they conquer" (82). Umuagu is similar to this Roman Empire, for it is not only territories that it conquered violently - people too are similarly brutalized. Moreover, Robert Maslen argues that the power of Titus Andronicus derives essentially from the way Shakespeare uses the body as a vehicle to demonstrate the intense destructive power of violence. He contends that this particular fact is embodied by Titus's daughter, Lavinia, who is raped by Demetrius and Chiron, Tamora's two sons, after which they sever her tongue from her mouth and cut her hands. Lavinia's brothers are not spared either; they are beheaded for a crime they did not commit, while Titus is also tricked by Aaron into cutting off his left hand with the hope that it will convince the jury to spare his sons' lives (Maslen 916). The spate of "body violence" is completed by Titus, who kills Demetrius and Chivon, then makes them into a pie, which he serves to Tamora. Thereafter, he kills Tamora but is himself killed by Saturninus, who is in turn killed by Lucius to avenge his father's death.

Like the Roman Empire thus painted, Umuagu also wages wars relentlessly against its adversaries, conquers other lands and surrounding territories in order to expand its own frontiers, hence living up to the meaning of its name, "Children of Lions." But, as Umuagu crushes its neighbors, so the men brutalize and repress their own wives and children as we see both in the case of Otaelo's parents and his own relationship with his fiancé, Princess Chinyere. Similarly to Titus Andronicus, the destruction of the body and the violence which accompanies private and public aggression are illustrated by Yerima in his treatment of how Otaelo's father assaults his wife, who kills him accidentally in retaliation. She is killed too, and her son, Otaelo, is ostracized and 
subjected to socio-cultural violence and cruelty through the Osu practice. But Otaelo himself carries out the spate of violence by killing his lieutenant, Ichiagu, out of jealousy, Chinyere out of suspicion and anger, and his greatest detractor, Agbo, for vengeance. Therefore, rather than a play that mirrors Othello (its main source), Otaelo conveniently assumes the character of a revenge play similar to Titus Andronicus.

Moreover, like Titus's, Otaelo's revenge mission against his society ends in a spate of deaths including his own. According to Victor Cahn, Titus Andronicus belongs to the genre of Elizabethan revenge tragedy, which is modeled on the Senecan/Roman tradition and is marked by "sensationalistic violence" that deals with the protagonist's quest for vengeance, which eventually proves more damning than the one which provoked it. As Cahn writes, revenge plays of this kind usually have a plot focusing on a single figure "who pursues a path of revenge that proves not only more destructive than the initial violence that provoked it, but also brings about the revenger's downfall" (5). Besides, Otaelo's main antagonist, Agbo, is cast in the mould of Aaron in Titus Andronicus. Except for his lover, Tamora, and her sons, Aaron thinks very little of the other characters, most especially Titus's family; he ascribes little importance to them: "But I have done a thousand dreadful things / As willingly as one would kill a fly / And nothing grieves me more heartily indeed / But that I cannot do ten thousand more" (5.1.141-4). Similarly to Aaron's, Agbo's actions are not only deliberate, but he also does not hide this fact. He warns that the game that he plays with the lives of his perceived enemies and loved ones knows no rules and feeds on blood (Yerima, Otaelo 38). When Otaelo returns to Umuagu as the hero of the battle, is feted by the Igwe, whose life he saved twice ("I grant you life. I grant you a higher role than Otaelo" [Yerima, Otaelo 16]), and granted his wish to marry the Igwe's daughter, Princess Chinyere, whom he has befriended secretly, Agbo is consumed by both jealousy and rage. He feels humiliated by the honor bestowed upon Otaelo: "an Osu is no man ... but food for the gods. So I was brought up to know" (Yerima, Otaelo 35). He does not hide his bitterness: "I killed more men than Otaelo. I am the head of the army, if anyone is to be made the Igwe of Abaniekpo, it should have been me" (29). In a conversation with another character, Ezeugo, Agbo insists that to accord Otaelo any respect whatsoever is "the enthronement of abomination. The glorification of Osu, the death of agelong tradition"; hence he decides to "save" tradition, "not for my sake, but for the sake of my people" 
(29-30). Consequently, he devises a deadly plan to achieve his aim by deceiving his wife and Princess Chinyere's friend, Obiageli, into bringing the princess's jigida (waistline bead), given to her by Otaelo as a sign of his undying love for her (36-37). Agbo collects the jigida from Obiageli, who thinks that he plans to give it to a stringer to produce a replica for her as he promised. Instead, he gives the jigida to Ichiagu, who loves and respects Otaelo in spite of his Osu status, but whom Otaelo accuses of cowardice and dismisses. Agbo advises Ichiagu to return the jigida to Chinyere, who might in turn help him to beg for Otaelo's forgiveness: "I think if you gave the jigida to her, it would melt and gladden her heart. You will then be able to curry back the favour of our great hero" (46). As soon as Ichiagu hurries off to carry out the task, Agbo informs Otaelo that he suspects Chinyere is having an affair with Ichiagu and can prove it with the jigida in Ichiagu's possession. On hearing this news, Otaelo confronts Ichiagu, finds the jigida on him and kills him in anger. He hurries to question Chinyere, who is unable to produce the jigida on demand but insists that she is not having an affair with Ichiagu. Unconvinced, and feeling both angry and humiliated, Otaelo strangles and kills her with the same jigida that he has earlier retrieved from Ichiagu. But he realizes his error when Obiageli arrives at the scene and tells him that she was the one who took the jigida from Chinyere on Agbo's request. Otaelo, having realized his folly, turns on Agbo and kills him; thereafter he commits suicide without resolving the crisis of his identity. Upon seeing the destruction caused by Otaelo, the Igwe loses his mind, while the land is thrown into confusion, silence, and mourning.

Whereas Western analyses have shown Othello's plot to be symmetrical in terms of white vs. black, Christian vs. Islam, and Europe vs. Ottoman Empire (see, for example, Bartel 433-54; Neill 44-47), and although the stories in both plays are similar in terms of the issues of discrimination and racism, the thematic concern and the source of conflict in Otaelo are markedly different from Othello's. Yerima also diverges from Shakespeare through the cultural specificity of his play, including the social circumstances of his protagonist. According to Loomba, Othello is on the one hand "a fantasy of interracial love and social tolerance, and a nightmare of racial hatred and male violence," and the play allows us to see that "skin colour, religion, and location were often contradictorily yoked together within ideologies of 'race', and all these were animated by notions of sexual and gender difference" (91-93). On the other hand, Loomba contends that racism should 
never be construed as determined solely by skin color for the relationship among a particular set of people or race can also be determined by segregation, so far as it is sanctioned by cultural norms (142-43). This statement applies to Umuagu's socio-cultural and political reality. Although Otaelo and his mother are members of the community, they are at the same time also aliens in that same society. They are both treated as outsiders. Otaelo's search for answers to such a deep-seated revulsion of his society toward him is summarized by Ebuka. According to Ebuka, "A dog is still a dog; and a hyena, a hyena, even though their faces bear a resemblance" (Yerima, Otaelo 33), which means that even though Otaelo breathes the same air and stands on the same ground as others in his community, his types are worthless in that society.

This also means that social reaction toward Othello in Venice and Otaelo in Umuagu constitutes a major part of the stimulus that determines how both characters react to their societies. Although Othello experiences hatred in Venice, a foreign land, due to the color of his skin, he is still elevated and honored. In turn, he respects Venice to the extent that he brings to it his own sense of civility. In his first appearance in the play, he does not brandish his sword unlike the others, whom he cautions: "Keep up your bright swords, for the dew will rust them / Good signor, you shall more command with years / Than with your weapon" (1.2.58-60). On the account of the respect that he is accorded, Othello also respects and defends Venice in return. After defeating the Turks, he also shows restraint in victory by cautioning his men about unnecessary celebration: "Let's teach ourselves that honourable stop / Not to outsport discretion" (2.2.3-4), whereas Otaelo, because he is despised and denigrated in Umuagu, has little respect for the community and does not hesitate to react violently toward people based on suspicion. Unlike Othello, he boasts of his prowess in battle: "I did it. I took my life in my hands, and see what I am today ... I said yes and my Chi bellowed in agreement" (Yerima, Otaelo 33). He is also arrogant and becomes power-drunk to the extent that he dismisses his lieutenant and trusted friend, Ichiagu, whom he accuses of cowardice: "why do you want a coward and a hero to dine on the same plate ... I want to excel not to be brought down by a weeping bull ... now leave me!" (32). In short, he feels and acts completely transformed.

Without any regard to decorum, Otaelo disowns the Osu group that he belongs to and dismisses Ebuka's warning with a wave of his hands: "Deep down in me I feel calm ... Go old man. Go tell 
your people. Tell them that I have left them. Tell them that I raise my head above their shame" (33-35). But because Ebuka understands fully the deep-seated nature of the Osu tradition and its destructive potentials, he warns Otaelo to be wary of his decoration by the Igwe and the uncertain direction of his changing fortune: "What are you doing here among vultures waiting for you to fall? Why have they built your hut so far away from theirs as if you reek of stench? Why do they treat you like a leper and yet call you a king?" (34) Overwhelmed with adulation from everyone, Otaelo rants at Ebuka: "through bravery I turn my black blood red" (34) - "black blood" here meaning his Osu status. Yet, Ebuka persists: "Your heart is heavy son. Ala wants you back" (35), but Otaelo's misplaced assumption about his future holds a stronger appeal than Ebuka's conviction about the danger that lies ahead of the young man.

Chinyere's arrival shortly after Ebuka's exit marks the point of reversal in Otaelo's fortunes; her entrance changes everything, including the course of the story and the fate of the protagonist. At first the lovers renew their love for each other and seal it with an oath. Afterward, Otaelo gives her a set of waistline beads, jigida, the only object that his mother left him as legacy (36-37). Rather than being an object of love, as intended, the jigida is turned into a tool of destruction by Agbo who "invests" it with deadly significance. Ostracism and the revulsion of society against his person, including the uncertainty about his identity, make Otaelo paranoid and on the alert for any prospect of betrayal from Chinyere, who unfortunately is unable to produce the jigida upon his demand. Otaelo strangles her with the same jigida he retrieved earlier from Ichiagu but also commits suicide after killing Agbo; it is his paranoia that destroys him as well as both his lover and adversary.

Cahn argues that from the first statement that is uttered in Hamlet, "Who's there?" (1.1.1), it is clear that the play deals with identity and the search for "real" personhood, which is the dilemma of every human being, informed by the need to define one's place and role in any given circumstances, irrespective of place and time (60). So far, I have shown that Yerima addresses the same question of identity in Otaelo, where relationship is determined by segregation, and that he treats the issue in the context of a cultural practice with far-reaching political dimensions. Whereas "Something is rotten in the state of Denmark" (1.4.90), which makes Hamlet's "crisis of identity" and the quest to avenge his father's death both dramatic and tragic, something is much more rotten in Umuagu, which allows us to view Otaelo's anguish with fear and pity. While the two plays treat the issue of 
identity, it is clear that the cultural context of Otaelo makes its own approach rather different from Shakespeare's.

According to Ikenna Nzimiro, Igbo society is classified based on being and / or from the perspectives of "[f]reeborn (Nwadiani), slave (Ohu), royal descent, wealth and membership of prestige associations (title societies), and the political elite" (24). In this grouping, the Osu class is not listed, which means that Otaelo is not only subjected to social revulsion; his identity is "constructed in exclusivising idioms" within the structures and practice of his own society (Nzimiro 24). Any aspiration by the Osu in the context of the play, and Otaelo's in particular, is limited by the crisis of identity that their ostracized condition of existence has imposed on them, for in Umuagu, as Agbo says, the Osu "is no [wo]man ... but food for the gods" (Yerima, Otaelo 35). Although the Igwe attempts to elevate Otaelo, thereby helping him to gradually and systematically resolve this crisis, and while this move is honorable, the social uproar following his move, which is considered a sacrilege by the entire land, is unimaginable. Agbo is among the first set of people to raise alarm, "an osu runs wild in the land, you elders do nothing about it. The soldiers murmur, and the youths are restless. The elders must be careful in this matter" (29). Indeed, the elders are more careful than he thinks and are forthright in their response to the Igwe's redeeming acts. They inform him that the gods of Umuagu are angry with him, most especially because of his plan to have his daughter marry Otaelo, the Osu. At the Council of Elders meeting, where they address the issue, the elders tell the Igwe, "[t]he land rejects your intended action, the people reject your intended action"; an elder, Obiajulu, even suggests, "[l]et us call Otaelo, and tell him ... go to your people, pick a girl, and the palace will pay the bride price. Even that gesture is an abomination," and finally they resolve to end what they regard as a charade, "[l]et the osu go to his people" (26). In order to make the Igwe aware that the rejection notice is a finality, the diviner Okaramuo also hands him the verdict of the gods in case the Igwe goes ahead with the planned marriage:

Both the osu and his wife must never set foot on the soil of Umuagu again after they are married. No celebration must be made, only the handmaidens of six must dance at the wedding. No child from the marriage must be allowed to come to Umuagu. Before they leave, [the lgwe] must kill a goat to cleanse the land. And [he] must never set eyes on [his] daughter again until the day of [his] death. (28) 
The elders also offer several explanations for the Igwe's sudden interest in the outcast, Otaelo, which goes clearly against the established tradition. While some think he is "caught up in his fight with his father's ghost" (38), some others, particularly Obidigbo and Ekekwe, believe it is something much more dreadful. While the former thinks it is due to insanity - which is quite prophetic for, indeed, the Igwe eventually loses his mind upon seeing the unwholesome tragedy that is caused by his "unusual" effort to help Otaelo resolve his identity crisis - the latter considers something more deeply penetrating and spiritual:

Obidigbo: Indeed the spirit of his father is not with him.

Ekekwe: ... we had consulted the gods after he failed to sever the head of the goat for his father's Igwuaka with one stroke of the cutlass. We heard that he was drunk, and could not see clearly, but the spirit of his father had already been offended. When we called the Dibia, he said that the Igwe will continue to have bouts of madness, until he performs the same act at his father's grave.

Obidigbo: At his father's grave? Does an Igwe have a grave?

Ekekwe: Do not open my mouth too wide on the matter, at least where his father's head is buried

Rather than addressing the obvious problem of the consequences of marginalization caused by the Osu practice, the elders stress that the crisis involving Otaelo and the Igwe has spiritual implications. They also suggest that the Igwe's and Otaelo's fates are entwined. Moreover, while the crisis of identity is considered a spiritual matter, the reference to the Igwe's late father also draws attention to how Otaelo's late father was responsible for his son's station in life, which is a fact that Otaelo himself is well aware of and attempts frantically to correct. Hence, for example, he initiates the idea of the jigida and the oath which accompanies its exchange between him and Chinyere for a special reason, "to put my wild heart at rest" (76) - a statement that is a recognition of both his own irascible nature and that of his father, that is, the brutality of lust and power that best describes his father's treatment of his wife and Otaelo's mother.

Finally, Otaelo's unconscious fears and excessive acts of repression of the influence that his absent father exerts on his life, which often compel him to exhibit some impulsive (re)action that is bereft of wisdom, and which lead him to suicide, are equally suggested in the lgwe's handling of 
the delicate matter of honoring him against the open displeasure of his council of elders. It is at this unresolved emotional and identity crisis that we must look, ultimately, in order to appreciate fully how Yerima uses Otaelo to examine the travesty of the Igbo Osu system of segregation, and how he uses Shakespeare's play to seek for "knowledge without illusions" (Kott 285). Linda Woodbridge reminds us that Shakespearean tragedy provokes questions and takes on big issues by drawing our attention to the consequences of villainy and human malice, which work against the protagonists in the Bard's plays. But the reality of watching or reading such tragic plays, she contends, is that they appeal to us because they tell us the plain truth about death and human misery (Woodbridge 21-23). Considering also the tragedy that Otaelo dramatizes, especially the tragedy of the type that the Osu practice in Igbo society of Nigeria constitutes, Yerima has used his play to interrogate the continued veneration of the Igbo Osu practice, whose central feature is segregation and discrimination.

This essay examined Yerima's adaptation of and collaboration with Shakespeare through Othello, which he titles Otaelo. In his review of Marjorie Garber's Shakespeare After All, Harold Henkel refers to the timeliness of Shakespeare and the transcendent qualities for which his plays have been praised around the world. He contends that the plays and their characters seem always to be "modern," always to "us." Yerima has drawn from that timeliness of Shakespeare's characters and themes. Although he diverges from Hamlet through the cultural specificity of Otaelo, he nonetheless appears to heed Hamlet's advice to his players about "the purpose of playing, whose end, both at first and now, was and is, to hold, as 'twere, the mirror up to nature" (3.2.20-1), by also holding it up to his society to have a clearer, and dispassionate, look at itself. In the "Author's Note" to the play Yerima writes that "the Osu caste system is the most painful practice among the Igbo people. For it separates man from man. And the soul from existence. I have from the outside viewed how this practice has torn wonderful friends of mine apart. To date even after this play, the common sense of it eludes me" (Otaelo 6). With Otaelo, then, Yerima demonstrates his association with the Shakespeare canon and collaboration with the "Dead Man," Shakespeare, who offers him such a modest platform as it were to express his fears and concerns about occurrences in his own immediate milieu of experience. Brophy writes that, whether there is an agreement or not, collaboration occurs between writers of different age, clime, and experience in which the old work 
"achieves a new and uncanny meaning as its location and its outcomes move aside of any single individual's responsibility." To this end, this essay has also argued that, rather than view the relationship between Shakespeare and Yerima in terms of influence, it is more profitable to see that relationship in light of collaboration.

\section{Works Cited}

Bartel, C. Emily. "Making More of the Moor: Aaron, Othello, and Renaissance Refashionings of Race." Shakespeare Quarterly, vol. 1, no. 4, 1990: 433-54.

Bradley, A.C. Shakespearean Tragedy. 1904. Penguin Books, 1991.

Brophy, Kevin. "The Poetics of Collaboration." axon, vol. 10, no. 1, 2016, www.axonjournal.com.au/issue-10/recognising-collaboration. Accessed 28 Sept. 2017.

Burnett, Linda. "Redescribing a World: Towards a Theory of Adaptation in Canada." Canadian Theatre Review, no. 111, 2002, pp. 5-9.

Cahn, L. Victor. Shakespeare the Playwright: A Companion to the Complete Tragedies, Histories, Comedies, and Romances. Praeger, 1996.

Dike, E. Victor. "The Osu Caste System in Igboland: Discrimination Based on Descent." Committee on Elimination of Racial Discrimination, 5-23 Aug. 2002, Palace of Nations, Geneva. Report.

Doring, Tobias. “Dislocating Stages: Mustapha Matura's Caribbean Rewriting of Synge and Checkov." European Journal of English Studies, vol. 2, no. 1, 1998, pp. 78-93.

Drakakis, John. Alternative Shakespeares. Psychology Press, 1985.

Fischlin, Daniel, and Mark Fortier. General Introduction. Adaptations of Shakespeare: a critical anthology of plays from the seventeenth century to the present, edited by Fischlin and Fortier, Routledge, 2000, pp. 1-22.

Frye, Northrop. A Natural Perspective: The Development of Shakespearean Comedy and Romance. Columbia UP, 1965.

Garber, Marjorie. Shakespeare After All. Knopf Doubleday Publishing Company, 2008. 
Gilbert, Helen, and Joanne Tompkins. Post-Colonial Drama: Theory, Practice, Politics. Routledge, 1996.

Henderson, Diana E. Collaborations with the Past: Reshaping Shakespeare across Time and Media. Cornell UP, 2006.

Henkel, Harold. “Review: Majorie Garber, Shakespeare After All.” Regent Education Online. Accessed 10 Jan. 2018.

Holderness, Graham. The Shakespeare Myth. Manchester UP, 1988.

Idika, Mba. "Osu." Traditional Religion in West Africa, edited by Ade E.A. Adegbola, Uzima Press Ltd, 1983, pp. 23-25.

Kott, Jan. Shakespeare Our Contemporary. Translated by Boleslaw Taborski, Methuen, 1965.

Loomba, Ania. Shakespeare, Race, and Colonialism. Oxford UP, 2002.

Loomba, Ania, and Martin Orkin. Post-Colonial Shakespeares. Routledge, 1998.

Maslen, Robert. "Introduction to Titus Andronicus." The Complete Works of Shakespeare: The Alexander Text. Intro. Peter Ackroyd. HarperCollins Publishers, 2006. 916-17.

Neill, Michael, ed. The Oxford Shakespeare: Othello. Oxford UP, 2006.

Nzimiro, Ikenna. Studies in Ibo Political System, Chieftaincy and Politics in Four Niger States. Cass and Company Ltd, 1972.

Shakespeare, William. The Complete Works of Shakespeare: The Alexander Text. Introduction by Peter Ackroyd. HarperCollins Publishers, 2006.

Tiffin, Helen. "Post-Colonial Literatures and Counter-Discourse." Kunapipi - Journal of Postcolonial Writing and Culture vol. 9, no. 3, 1987, pp. 17-34, ro.uow.edu.au/kunapipi/vol9/iss3/4. Accessed 10 Jan. 2018.

Tompkins, Joanne. "Re-Citing Shakespeare in Post-Colonial Drama." Essays in Theatre / Etudes theatrales, vol. 15, no. 1, 1996, pp.15-22.

Woodbridge, Linda. "Tragedies." Shakespeare: An Oxford Guide, edited by Stanley Wells and Lena Cowen Orlin, Oxford UP, 2003, pp. 212-23. 
Yerima, Ahmed. Otaelo. Kraftgriots, 2002.

Yerima, Ahmed. Fragmented Thoughts and Specifics: Essays in Dramatic Literature. Bookplus, 2003.

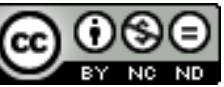

Creative Commons Attribution-NonCommercial-NoDerivatives 4.0 International License 